\title{
Imaging Drumlin Architecture with Electrical Resistivity
}

\author{
Januka Attanayake ${ }^{1}$, Yongping Chen ${ }^{1}$, Rory Henderson ${ }^{2,3} \&$ Zhao Zhao ${ }^{1}$ \\ ${ }^{1}$ Center for Integrative Geoscience, The University of Connecticut, Storrs CT, USA \\ ${ }^{2}$ USGS, Office of Groundwater, Branch of Geophysics, Storrs CT, USA \\ ${ }^{3}$ Civil \& Environmental Engineering, The University of Connecticut, Storrs CT, USA \\ Correspondence: Januka Attanayake, Physics Department, University of Connecticut, U3046, Storrs, CT, 06269, \\ USA. Tel: 1-860-970-2617. E-mail: jattanayake@yahoo.com
}

Received: January 4, $2013 \quad$ Accepted: August 23, $2013 \quad$ Online Published: October 23, 2013
doi:10.5539/jgg.v5n4p1
URL: http://dx.doi.org/10.5539/jgg.v5n4p1

\begin{abstract}
Geomorphologists may use the knowledge of interior structure of drumlins to infer finer-scale dynamics of glaciers. An electrical resistivity imaging study was carried out to investigate the interior architecture of a drumlin near UCCT seismic station located in the premises of the University Connecticut. Apparent resistivity measurements collected from an $81 \mathrm{~m}$-long dipole-dipole electrode array oriented along the longer axis of the drumlin were inverted to obtain a subsurface model. The model consists of four layers of different resistivity values. These results are used to infer a glacial depositional sequence of younger upper till and older lower till separated by a transition layer. Evidence for a basement crystalline rock core was not found at the maximum penetration depth of $17 \mathrm{~m}$.
\end{abstract}

Keywords: glaciers, drumlins, electrical resistivity, 2D inversion

\section{Introduction}

There are three main schools of thought that have been put forward to explain drumlin formation; basal deposition of drift from flowing ice, glacial deposition on top of pre-existing "knobs" of bedrock and a combination of erosional and depositional processes (Krüger \& Thomsen, 1984). Due to challenges associated with obtaining shallow depth information, confirming these hypotheses has been difficult. However, application of geophysical imaging techniques has yielded better constrains on drumlin architecture than traditional mapping methods (Raukas \& Tavast, 1994). Understanding drumlin architecture allows geomorphologists to infer glacial dynamics. For example, two controversial dynamical ideas were developed to explain drumlin formation; (a) deposition from a soft mobile subglacial debris zone (b) deposition from catastrophic subglacial flood events (Menzies, 1989). The link between drumlin architecture and these dynamic processes is not well established.

In Connecticut (CT), surficial material has a glacial origin of Quaternary age and the landscape is frequented by drumlins (Stone et al., 2005). At local-scale $(<10 \mathrm{~km})$, drumlin formation is governed by fairly uniform geomorphological processes is a reasonable assumption. In this study, we characterized the longitudinal cross section of a drumlin located within close proximity to the University of Connecticut seismic station (UCCT) using a simple two-dimensional electrical resistivity imaging experiment. The purpose of our investigation is two fold. We first determine the architecture of layering near the center of the drumlin. Secondly we test if a bedrock core can be observed at a shallow depth. To our knowledge, there is no literature available on geophysical imaging in CT to characterize drumlins although United States Geological Survey (USGS) has conducted several imaging projects for hydrogeological purposes. Secondly, surrounding our study site, there are several drumlins (Figure 1). Under the assumption we made earlier, we can infer the architecture of these drumlins to be the same as the one that we imaged. Inferring glacial dynamics related to drumlin formation, however, is beyond the scope of our work. We leave that up to geomorphologists.

Electrical resistivity profiling is a non-invasive, efficient and an economical technique of characterizing the shallow subsurface. It may be applied to investigate geological (Sudo et al., 2004), environmental (Özürlan \& Karaman, 2002) and engineering (Wolf et al., 1998) problems. In general, electrical resistivity of Earth materials falls in the range of $1-10^{8} \Omega \mathrm{m}$ (Figure 2). The remarkable contrast of electrical resistivity between hard rock basement and overlying wet unconsolidated sediment cover (in our case glacial till) can be used to determine the depth to bedrock. In our study, we observed evidence to suggest two different depositional regimes characterized 
by younger upper till and older lower till. In addition, we did not observe the interface between the basement crystalline rock and the drumlin till deposit in the $17 \mathrm{~m}$ deep profile we inverted for. The following section briefly introduces theory behind resistivity imaging. Then we present method and results. Next we dedicate a section to discuss our results. Finally, we present our conclusions.

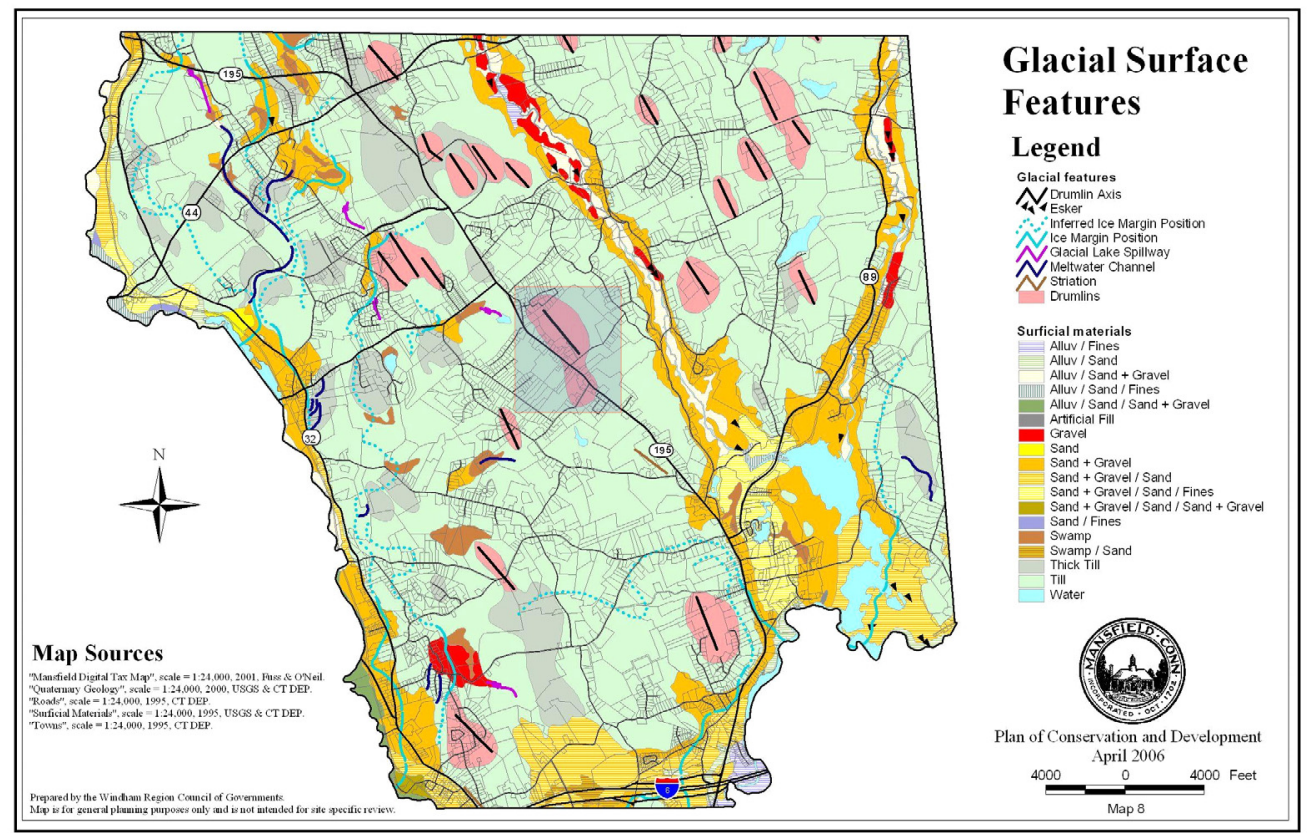

Figure 1. Glacial surface features map of Tolland county in Connecticut, USA. The landscape is frequented by drumlins shown as pink elongated bodies. The general orientation of long axis of drumlins predicts an ice flow direction from NNW to SSE. The shaded box in the center shows the study site (Plan of Conservation and development)

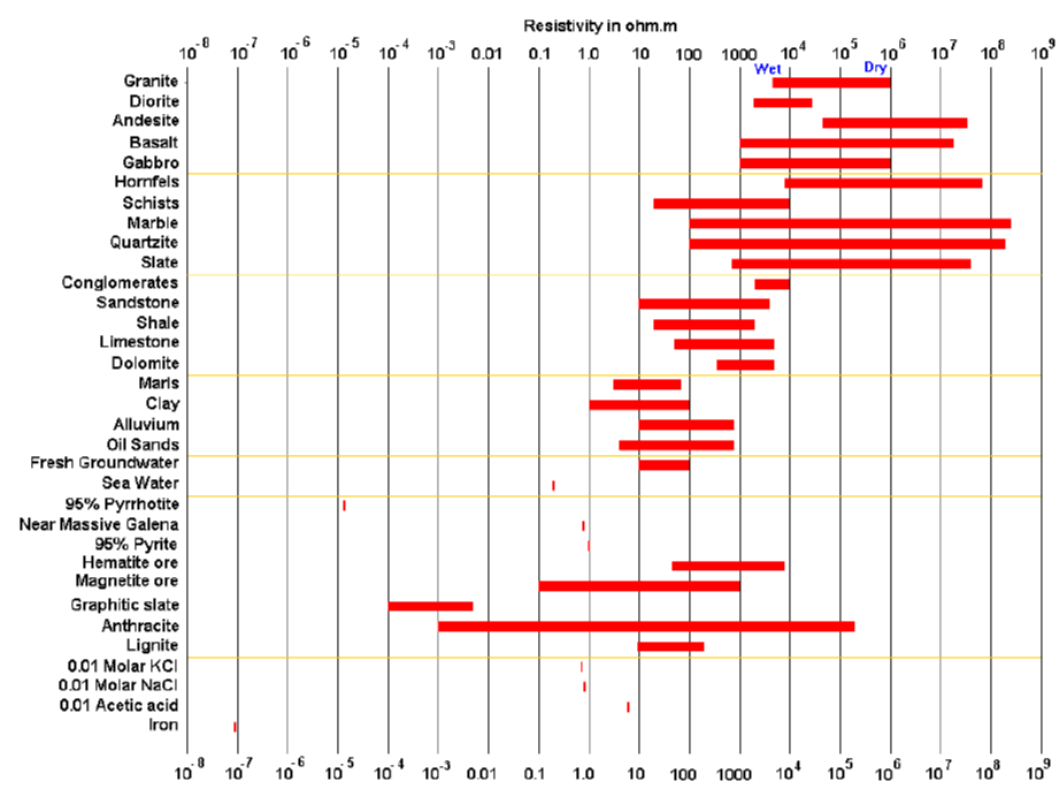

Figure 2. Electrical resistivity values of different Earth materials (Loke, 2004)

\section{Electrical Resistivity Imaging - Basic Theory}

Vector form of Ohm's law (1) defined for a current flow in a continuous medium governs the electrical resistivity technique. 


$$
J=\sigma \mathrm{E}
$$

Where $\mathrm{J}$ is the current density, $\sigma$ is the electrical conductivity and $\mathrm{E}$ is the electric field intensity in the medium. From the relationship $\mathrm{E}=-\nabla \varphi$ we could write,

$$
J=-\sigma \nabla \varphi
$$

Where $\varphi$ is the electric potential. Further, the following relationship can be obtained between $\mathrm{J}$ and the current (I) assuming that current flow occurs over an elemental volume $\Delta V$ surrounding the current source,

$$
\nabla \cdot J=\frac{I}{\Delta V} \delta\left(x-x_{0}\right)\left(y-y_{0}\right)\left(z-z_{0}\right)
$$

where, $\mathrm{x}_{0}, \mathrm{y}_{0}, \mathrm{z}_{0}$ are the coordinates of the current source. From (2) and (3),

$$
-\nabla \cdot[\sigma(x, y, z) \nabla \phi(x, y, z)]=\frac{I}{\Delta V} \delta\left(x-x_{0}\right)\left(y-y_{0}\right)\left(z-z_{0}\right)
$$

This is the forward model problem as it describes the potential distribution in the ground due to a point current source. In addition, it could be shown that for a system that has 2 current electrodes and 2 potential electrodes (Figure 3a), the apparent resistivity ( $\rho$ a) is

$$
\rho \mathrm{a}=k \frac{\Delta \varphi}{I}
$$

where $\mathrm{k}=2 \pi /[(1 / \mathrm{C} 1 \mathrm{P} 1)-(1 / \mathrm{C} 2 \mathrm{P} 1)-(1 / \mathrm{C} 1 \mathrm{P} 2)+(1 / \mathrm{C} 2 \mathrm{P} 2)]$ and $\Delta \varphi$ is the potential difference between the two potential electrodes. $\mathrm{C}_{\mathrm{i}} \mathrm{P}_{\mathrm{i}}$ denotes the distance between corresponding electrodes. Equations (4) and (5) constitute the basic theory behind resistivity technique given that resistivity, $\rho=1 / \sigma$ and the relationship between $\rho=\rho$ a is complex. (see Loke, 2004 for a review).
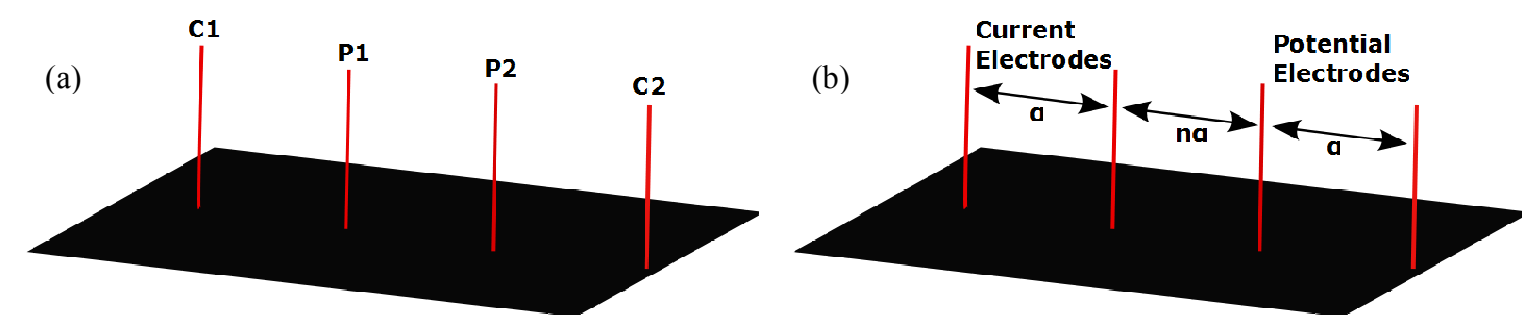

Figure 3. (a) Electrode configuration. $\mathrm{C} 1$ and $\mathrm{C} 2$ are current electrodes. P1 and P2 are potential electrodes. (b) Shows the dipole-dipole electrode configuration. The quantity "a" represents the separation between either current or the potential electrodes and "na" represents the separation between adjoining current and potential electrodes.

\section{Method and Results}

Our site belongs to the plant science department of the University of Connecticut and situated adjacent to the University seismic station UCCT at latitude $41^{\circ} 47^{\prime} 41^{\prime \prime}$ and Longitude $72^{\circ} 13^{\prime} 45^{\prime \prime}$ and at an elevation of nearly $600 \mathrm{ft} \mathrm{(} 200 \mathrm{~m}$ ) from the mean sea level (MSL). We used 28 electrodes at $3 \mathrm{~m}$ separation in a dipole-dipole (D-D) array oriented in the long axis direction (nearly North-South) of the drumlin (Figures $3 b$ and 4). The array was $81 \mathrm{~m}$ long and it gives us a maximum theoretical median penetration depth of more than $18 \mathrm{~m}$. Although the exact thickness of till is not known, Stone (2005) suggest that it may be greater than $100 \mathrm{ft}(>30 \mathrm{~m})$. Therefore, estimated penetration depth fall well short of the predicted till cover. We were unable to expand the D-D array to achieve greater depth penetration due to limited access we had to the total span of the drumlin. The topography along the D-D array is nearly flat and therefore, a topography adjustment was not needed. Data were gathered using an AGI sting swift Earth resistivity meter. 


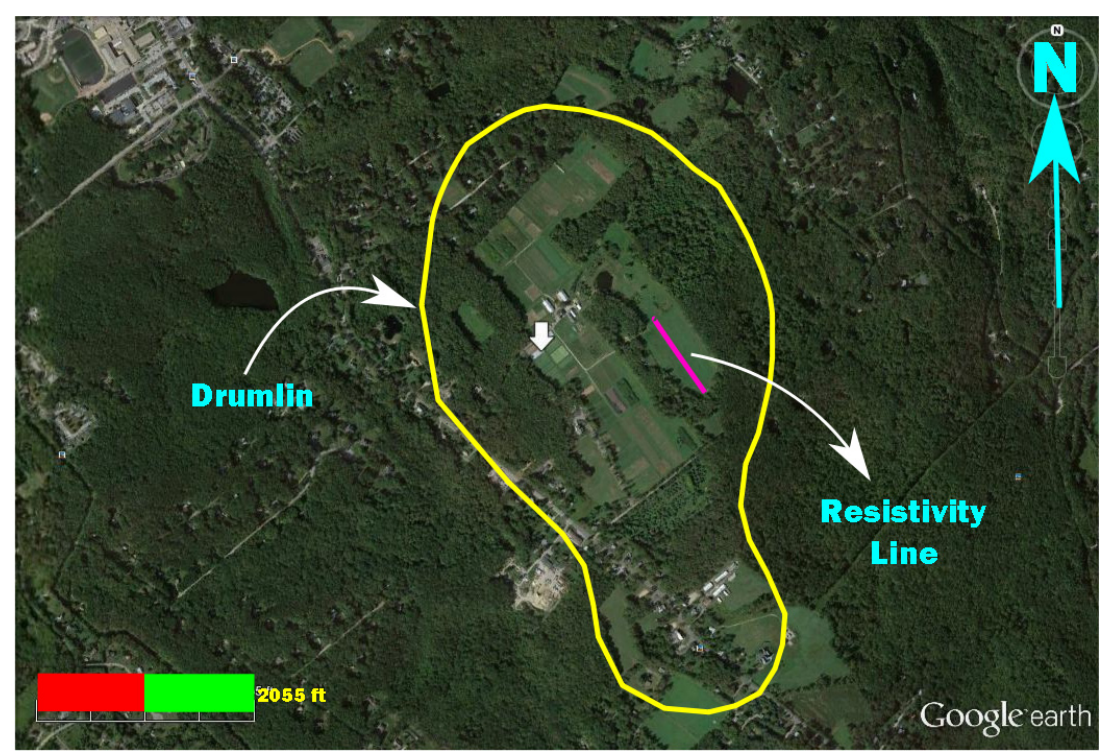

Figure 4. Google earth image of the study site. Rough boundary of the drumlin is shown in yellow. The orientation of the dipole-dipole electrode array is shown by the purple line (roughly to scale) and the white solid arrow within the drumlin shows the location of the USGS groundwater monitoring well

First we conducted a contact resistivity test and it appeared that along the line there is fairly high resistance. After pouring reasonable amount of salt water around electrodes to enhance the current flow in to the subsurface we managed to improve signal strength with North end showing higher resistance than the South end of the array. In the survey, a total of 262 data points were recorded in 21 datum levels of which repeated ones were removed leaving 257 datum points for the inversion (Figure 5). Inversion was carried out using RES2DINV program (Loke, 2004).

Forward modeling was handled by finite-element method. A factor of 1.00 to increase the layer thickness with depth was introduced and the first layer thickness to unit electrode spacing was reduced to 0.25 . The number of model blocks (337) was allowed to exceed the number of datum points (257). With this configuration the layer model had 24 layers with relatively smaller cell blocks (Figure 6). Effect of side blocks was reduced and poor datum points in the North end were removed from the surface line. Results of the inversion are given in Figure 7 and the subsurface sensitivity for this model is given in Figure 8. As expected, the sensitivity decreases with depth. This is characteristic of resistivity imaging, which is governed by diffusion equations. One must keep in mind that the image resolution in the bottom layers is not as high as that in the surface layers. That said, reliability of the resistivity profile remains intact given the data point coverage in each layer. The maximum reliable depth of penetration is closed to $17 \mathrm{~m}$ and agrees with the theoretical estimate. 


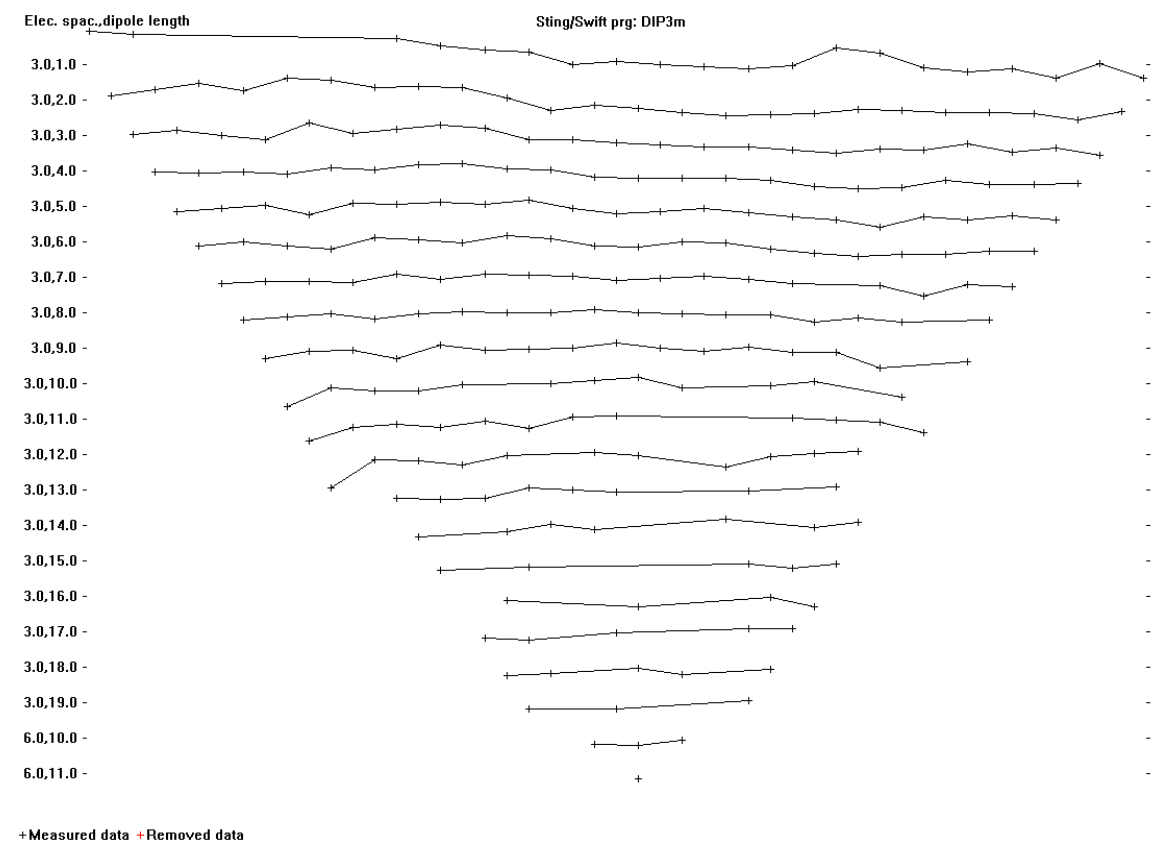

Figure 5. Distribution of datum points after removing poor data points from the North (left) end. 257 data points are used in the inversion

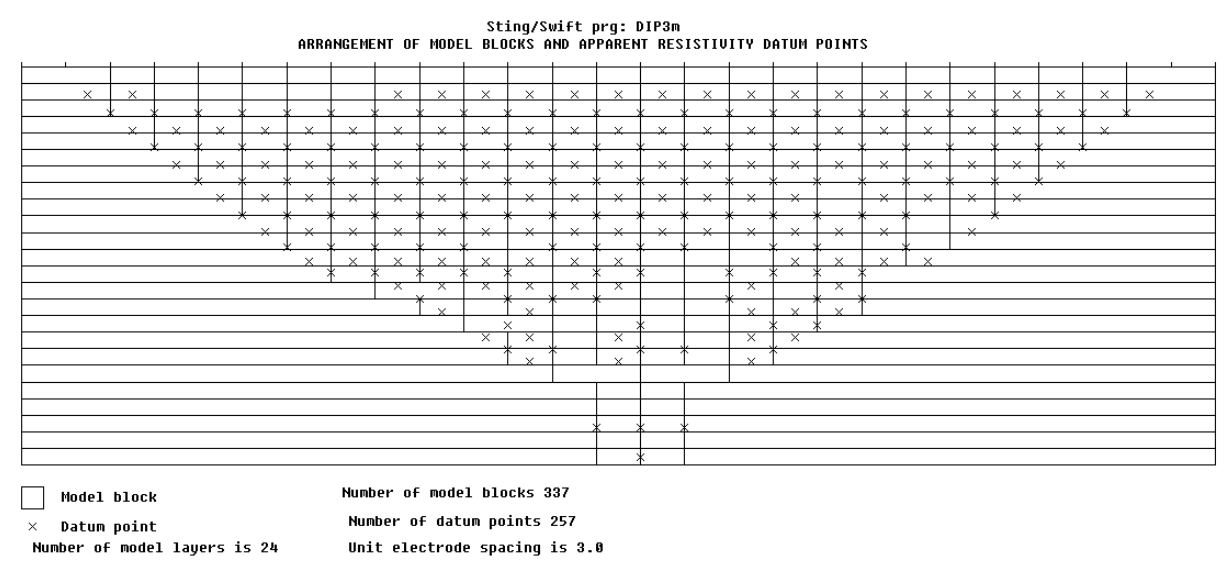

Figure 6. A map of the cell blocks constructed for the inversion. There are 24 horizontal layers and 332 cell blocks

The entire subsurface profile shows relatively low resistivity values except for the surface layer. We clearly identify four distinct layers based on resistivity values; A surface layer with high resistivity $(>1000 \Omega \mathrm{m})$ of about $2.5 \mathrm{~m}$ thickness, a low resistive $(100-250 \Omega \mathrm{m})$ region immediately below the surface layer of a maximum $5 \mathrm{~m}$ thickness, a third layer of moderate resistivity $(250-500 \Omega \mathrm{m})$ of $4 \mathrm{~m}$ thickness and the bottom most layer with a resistivity of $<250 \Omega \mathrm{m}$. The surface layer shows systematic low-to-high resistivity transition in a South-to-North (right-to-left) direction. In addition, its thickness appears to increase in the same direction. Resistivity values of the second layer clearly indicate that it contains significant amount of moisture. The thickness of this layer increases towards the south end along with conductivity (reciprocal of resistivity) indicating that the south side is holding more water. It may be that water is draining towards the southern end of the D-D array. The third layer shows higher resistance than the second layer. Also, the boundary between these layers is relatively sharp and it leads us to believe that the third layer is fairly dry and impermeable than the second layer. In the center of this layer, below the $39 \mathrm{~m}$ mark (horizontal distance), we observe a high resistive patch. Notice the slight tilt that this layer exhibits. Although the D-D array is positioned at the center of the drumlin and the surface is relatively flat, the underlying layers seems to "shape" towards either end of the drumlin. The bottom most layer has the least number of data points to constrain its properties. Hence it has the 
lowest sensitivity levels as shown in the sensitivity map. It shows reduced resistivity levels relative to the over lying layer and the homogenous nature of resistivity can be explained by the loss of sensitivity and resolution at depth. The reduction in resistivity may be explained by the presence of a rather shallow groundwater table in this region. This reasoning is justified by the recordings of a near by USGS groundwater monitoring well whose location is shown in Figure 4.

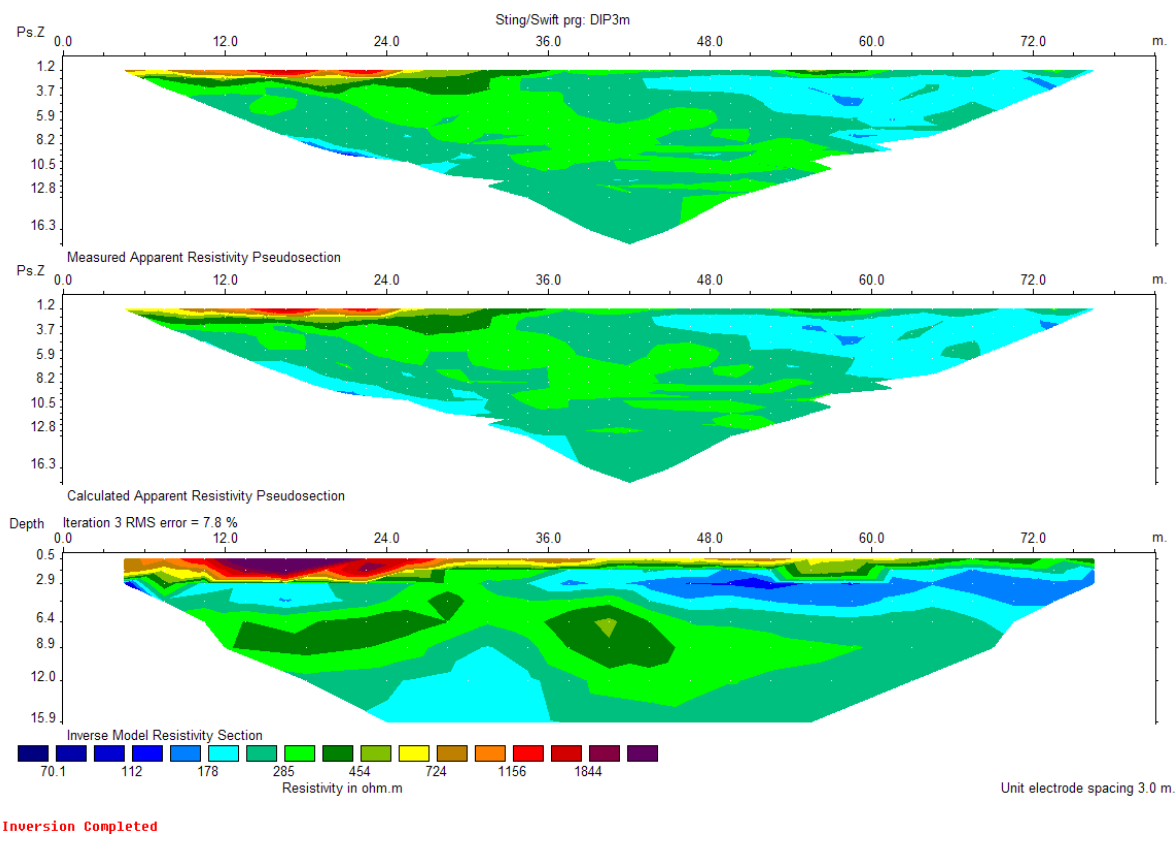

Figure 7. Results of the inversion. Top panel: Observed apparent resistivity pseudo section. Middle panel:

Estimated apparent resistivity pseudo section. Bottom panel: inverted model

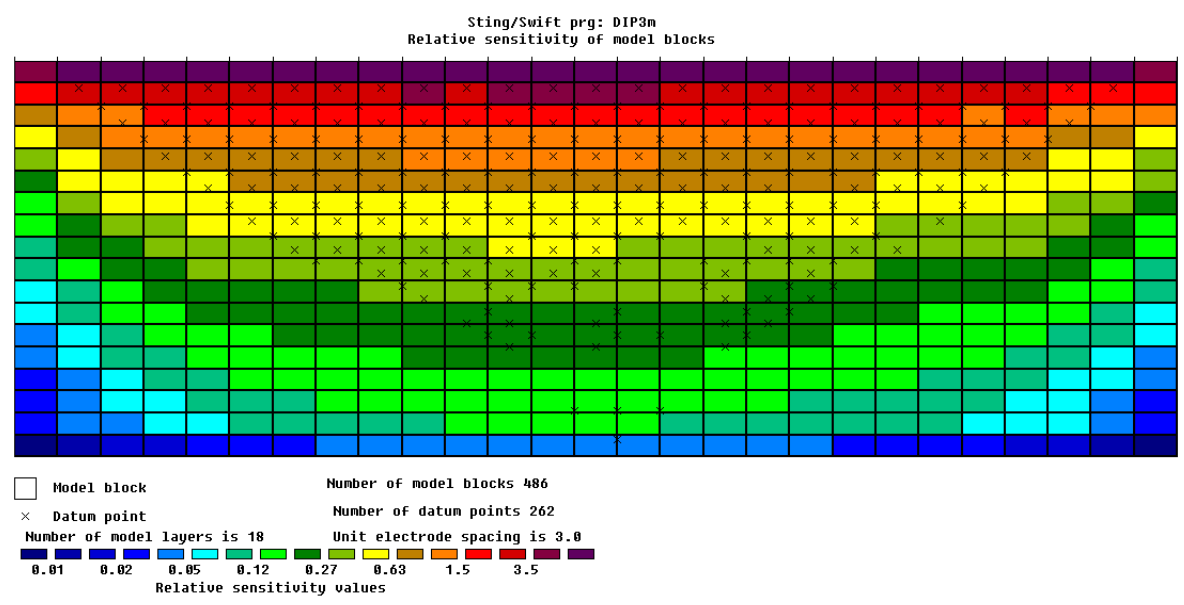

Figure 8 . Sensitivity map of the model

\section{Discussion}

During the quaternary period Connecticut has undergone significant landscape modification due to glacial activity. One of the wide spread depositional landforms is drumlins and their surface physical features such as height, width and length have been effectively used to predict geologic and topographic controls on the direction of the ice flow (primarily NNW to SSE) at regional scale (Boling \& Wizevich, 2010). Understanding of the interior structure of individual drumlins, however, may bring finer scale details about the dynamics of glacial activity to light. Two different tills, younger upper till and older lower till, of different character and time of origin are found in Connecticut (Stone et al., scientific investigations Map 2784). The younger upper till is over lying lower older till with the latter making up bulk of the material in drumlins. According to surficial material 
map of Connecticut, our study site falls within an area where this till-configuration is observed. Further, it is predicted that the entire till cover can be more than $100 \mathrm{ft}(>30 \mathrm{~m})$ deep with the top four to five meters occupying younger upper till.

Our resistivity profile can be made consistent with this sediment configuration. The surface layer obviously shows high resistivity and reaches a maximum thickness of about three meters. Upper till is loosely bound and therefore, water can easily percolate through it. Relative dryness along with stony and sandy material, of which the first layer is made up, might explain the higher resistivity we observed. A zone of closely spaced joints and oxidation (iron, manganese), a layer representing inter-glacial weathering, characterizes the interface between the upper till and the lower till. This may explain very low resistivity values (high conductivity) in the second layer. In other words, the second layer from the top seen in our resistivity profile that reaches a maximum thickness of about four meters, may indeed represent the interface between upper till and lower till. Lower till is considered to be moderately to highly compacted, less stony than upper till and is fine grained. The increase in resistivity from the second layer to third layer can be explained if one assumes a layer of lower till underlying the second layer (the transition), where groundwater movement is relatively inhibited due to compaction of fine-grained till material. The moderately high resistive "patch" appearing in the center of this layer may correspond to heterogeneity in lower till. It is reasonable to incorporate heterogeneity to glacial till because these are unsorted sediments derived usually from different sources. Further, the geometry of this layer and the bottommost layer may be related to earliest drumlin formation and subsequent inter-glacial erosion. One other significant feature of our inversion result is that we did not observe evidence to suggest a bedrock core in the top $17 \mathrm{~m}$ of the drumlin. The underlying basement rock in this region is Hebron gneiss, a crystalline rock inter-layered with dark gray schist and greenish gray fine-to medium grained calc-silicate gneiss with an average dip of $30^{\circ}$ in a NNW direction (Figure 9).

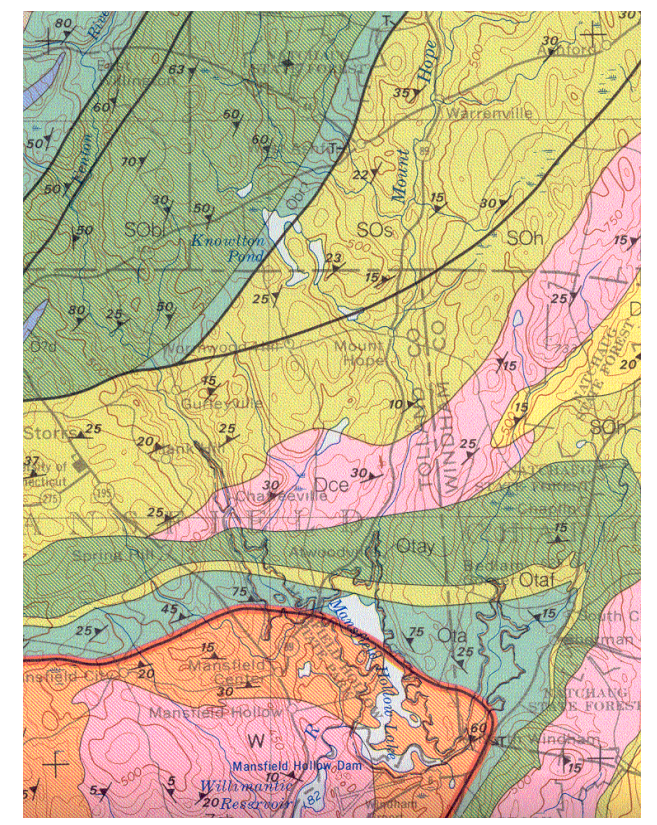

Figure 9. Regional geologic map. The general dip is $30^{\circ}$ to NNW (see quadrangle 41, namely Spring Hill quadrangle, at http://tmsc.org/geology/bedrock/ for the legend)

Resistivity values of crystalline rock and till differ significantly. If the interface between these vastly different earth materials was found within the area our investigation is sensitive to, a strong resistivity transition from low-to-high should occur. The lack of such a feature confirms that sediment cover extends well beyond a depth of $17 \mathrm{~m}$. As previously mentioned, geologic field predictions put the thickness of till in drumlins at more than 30 $\mathrm{m}$. Our results are consistent with this prediction based on surface observations.

\section{Conclusions}

We investigated the architecture of a drumlin using two dimensional electrical resistivity imaging. The inverted model showing four distinct zones can be made consistent with already existing field geologic predictions. The surface material is characterized by a layer of high resistivity of $3 \mathrm{~m}$ thickness and can be made consistent with 
younger upper till consisting of a stony loosely bound fine-to-medium grained sandy matrix. The very low resistivity layer underlying the surface layer may be the closely jointed, oxidized zone representing inter-glacial weathering between the upper till and the older lower till. Below the second layer we observe two layers that are fairly dry as indicated by resistivity values higher than that of the second layer but are much lower than the surface layer. These bottommost layers can explain the presence of older lower till in the interior of the drumlin. Finally, we do not observe the interface between the basement crystalline rock and the glacially deposited till within the top $17 \mathrm{~m}$ that we imaged.

\section{Acknowledgement}

This research was supported by the Center for Integrative Geosciences at the University of Connecticut and we thank Professor Lanbo Liu and Eric White for their assistance in carrying out this work.

\section{References}

Bedrock geology map of Spring Hill quadrangle. (2012). In online version of Face of Connecticut maintained by Talcott Mountain Science Center. Retrieved August 1, 2012, from http://msc.org/geology/

Boling, K. S. (2010, March). Understanding Controls on Connecticut Drumlin Morphology, Location, and Orientation Using Lidar and Gis Analyses. In Geological Society of America Abstracts with Programs, (Vol. 42, No. 1, p. 67).

Loke, M. H. (2004). Tutorial: $2 D$ and $3 D$ electrical imaging surveys. Retrieved from www.geoelectrical.com

Mansfield Plan of conservation and development. (2006). Mansfield planning and zoning commission, CT. Retrieved from http://www.mansfieldct.gov/filestorage/1904/1932/2043/map_06.jpg

Menzies, J. (1989). Drumlins_-Products of controlled or uncontrolled glaciodynamic response? Quaternary Science Reviews, 8(2), 151-158. http://dx.doi.org/10.1016/0277-3791(89)90003-6

Özürlan, G., \& Karaman, A. (2002). Characterizing water-level changes due to fracturing generated by the strike-slip fault of the 12 November 1999, Düzce, Turkey, earthquake using the VLF method. Environmental Geology, 42(1), 61-64. http://dx.doi.org/10.1007/s00254-002-0529-8

Quaternary Geologic Map of Connecticut and Long Island Sound Basin, Scientific Investigations Map 2784, USGS.

Raukas, A., \& Tavast, E. (1994). Drumlin location as a response to bedrock topography on the southeastern slope of the Fennoscandian Shield. Sedimentary geology, 91(1), 373-382. http://dx.doi.org/10.1016/0037-0738(94)90141-4

Stone, J. R., Schafer, J. P., London, E. H., DiGiacomo-Cohen, M. L., Lewis, R. L., \& Thompson, W. B. (2005). U.S. Geological Survey Scientific Investigation Map 2784, 2 sheets, scale 1:125,000.

Sudo, H., Tanaka, T., Kobayashi, T., Kondo, T., Takahashi, T., Miyamoto, M., \& Amagai, M. (2004). Permeability imaging in granitic rocks based on surface resistivity profiling. Exploration Geophysics, 35(1), 56-61. http://dx.doi.org/10.1071/EG04056

Wolf, L. W., Collier, J., Tuttle, M., \& Bodin, P. (1998). Geophysical reconnaissance of earthquake-induced liquefaction features in the New Madrid seismic zone. Journal of applied geophysics, 39(3), 121-129. http://dx.doi.org/10.1016/S0926-9851(98)00016-0

\section{Copyrights}

Copyright for this article is retained by the author(s), with first publication rights granted to the journal.

This is an open-access article distributed under the terms and conditions of the Creative Commons Attribution license (http://creativecommons.org/licenses/by/3.0/). 